SCHEEFFER, Fernando. Esquerda, direita e "novos" temas na Câmara dos Deputados. Revista Eletrônica Direito e Política, Programa de Pós-Graduação Stricto Sensu em Ciência Jurídica da UNIVALI, Itajaí, v.12, n.3, $3^{0}$ quadrimestre de 2017. Disponível em: www.univali.br/direitoepolitica - ISSN 1980-7791

\title{
ESQUERDA, DIREITA E "NOVOS" TEMAS NA CÂMARA DOS DEPUTADOS
}

\author{
LEFT, RIGHT AND "NEW" ISSUES IN THE CHAMBER OF DEPUTIES
}

Fernando Scheeffer ${ }^{1}$

SUMÁRIO: Introdução; 1 procedimentos metodológicos; 2 esquerda e Direita: velhas ideologias cedem lugar a novas?; 3 Análise e discussão dos resultados; 3.1 Código Florestal Brasileiro (PL 1876/1999); 3.2 Rotulagem de transgênicos (PL 4148/2008); 3.3 Cotas para concurso público (PL 6738/2013); 3.4 Criminalização de práticas indígenas nocivas (PL 1057/2007); 3.5 Plano Nacional de Participação Social (PDC 1491/2014); 3.6 Criação da Comissão Nacional da Verdade (PL 7376/2010); 3.7 Identidade de gênero (PL 7699/2006); 3.8 Cotas para mulheres no legislativo (PEC 182/2007); Considerações finais; Referências das fontes citadas.

\section{RESUMO}

Além da atualização do significado da terminologia esquerda e direita, na Ciência Política um dos focos de interesse recente é a verificação do grau em que as supostas diferenças ideológicas entre os partidos acarretam diferentes posicionamentos dos atores políticos. Diante desse cenário, o presente trabalho busca saber qual o peso da ideologia na Câmara dos Deputados se atendo à análise de votações nominais envolvendo "novos" temas que se fazem presentes no debate contemporâneo e que extrapolam a tradicional dimensão Estado versus mercado. São analisados temas substantivos do ponto de vista político-ideológico e que, em tese, implicariam em dissenso entre parlamentares e partidos de esquerda e de direita. A fim de confrontar o peso da ideologia com o posicionamento estratégico dos partidos, para cada lei foi aplicado o modelo de regressão logística. Em todos os temas a ideologia sobrepujou a relação dos partidos com o executivo. Analisando o posicionamento efetivo dos parlamentares em relação aos temas em questão, a ideologia prevalece e os partidos em sua maioria se posicionam de forma coerente com o que é esperado do ponto de vista político-ideológico.

PALAVRAS-CHAVE: Direita; Esquerda; Ideologia; "Novos" temas; Câmara dos Deputados

\section{ABSTRACT}

In addition to updating the meaning of left and right terminology, in Political Science one of the main focus recent is the verification of the grade in which the so supposed ideological diferences between political parties interfere in the

1 Doutor em Sociologia Política (UFSC), professor da Universidade do Estado de Santa Catarina (UDESC), Ibirama, SC, e-mail: fernando.scheeffer@udesc.br 
SCHEEFFER, Fernando. Esquerda, direita e "novos" temas na Câmara dos Deputados. Revista Eletrônica Direito e Política, Programa de Pós-Graduação Stricto Sensu em Ciência Jurídica da UNIVALI, Itajaí, v.12, n.3, $3^{0}$ quadrimestre de 2017. Disponível em: www.univali.br/direitoepolitica - ISSN 1980-7791

behavior of political actors. In this scenario, the presente study is proposing to verify the weight of ideology in the Chamber of Deputies starting from the analysis of a set of roll call votes involving post-materialist issues that have been presente in the contemporany debates and and that extrapolate the traditional state vs. market dimension. Substancial themes were analysed from the political-ideological point of view, themes taht in thoery would envolve disagreements between parliamentarians and parties from left and right. In order to confront the weight of ideology with the strategic positioning of the parties, for each law the logistic regression analysis was applied. In all themes the ideology overcame the relationship of the parties with the executive. Analyzing the effective position of parliamentarians in relation to "new" issues, ideology prevails and the parties in their majority stand themselves coherently with that is expected from the ideological-political point of view.

KEYWORDS: Right; Left; Ideology; "New" issues; Chamber of Deputies

\section{INTRODUÇÃO}

Em tempos atuais não se tem consenso sobre a relevância das ideologias políticas, sobretudo enquanto preditoras do comportamento parlamentar. Dentre as variáveis concorrentes à ideologia destaca-se o pertencimento ao governo e à oposição. Autores como Zucco Jr., por exemplo, acredita que tenhamos evidências o suficiente para acreditar que a ideologia nos últimos anos tem se tornando um determinante pouco relevante do comportamento legislativo na Câmara dos Deputados. Para ele a clivagem estratégica (governo/oposição) se sobrepõe à ideológica ocupando papel predominante e pautando a disputa política em tempos atuais. ${ }^{2}$ Já para Maria D'Alva Kinzo a ideologia se demonstra um componente importante quando inseridas no debate questões relevantes. Analisada a atuação dos partidos na Constituinte propõe que, diferente do que se possa imaginar, interesses pessoais e eleitoreiros dão lugar a posições distintas e claras entre os partidos que sugerem um componente ideológico presente e duradouro. ${ }^{3} \mathrm{O}$ comportamento legislativo é calcado predominantemente na concorrência entre

2 ZUCCO JR., C. Ideology or what? Legislative behavior in multiparty presidential settings. The Journal of Politics, v. 71, p. 1.076-1.092, 2009.

Esquerda, direita e governo: a ideologia dos partidos políticos brasileiros. In: POWER, T.

J.; ZUCCO JR. (orgs). O congresso por ele mesmo: autopercepções da classe política brasileira. Belo Horizonte: Editora UFMG, 2011.

3 KINZO, M. D. O quadro partidário e a Constituinte. In: LAMOUNIER, B. De Geisel a Collor: o balanço da transição. São Paulo: Sumaré, 1990. 
SCHEEFFER, Fernando. Esquerda, direita e "novos" temas na Câmara dos Deputados. Revista Eletrônica Direito e Política, Programa de Pós-Graduação Stricto Sensu em Ciência Jurídica da UNIVALI, Itajaí, v.12, n.3, $3^{\circ}$ quadrimestre de 2017. Disponível em: www.univali.br/direitoepolitica - ISSN 1980-7791

essas duas variáveis fundamentais: oposição/situação e ideologia. Seriam dois tipos distintos de implementação de agendas e a pergunta fundamental seria: não negado o presidencialismo de coalizão e a formação de coalizões majoritárias, será que a variável ideologia não se sobressai em temas com cunho ideológico presentes na agenda política?

As várias divergências em relação a essa temática deixam clara sua complexidade e sugerem ser este um campo promissor de estudo. Embora os estudos legislativos ocupem hoje uma área de destaque na Ciência Política brasileira, são muitos os espaços para aprofundamento dos estudos legislativos brasileiros, sobretudo da variável posição ideológica. ${ }^{4}$ Se até 2002 falar em governo e oposição era semelhante a falar em esquerda e direita dada a composição de blocos coesos ideologicamente, a partir de 2003 o cenário se complexifica. As coalizões passam a contar com um maior número de partidos e de todos os campos ideológicos. A dificuldade está, nesse caso, em discernir se o comportamento dos partidos em plenário deve-se às ideologias dos partidos ou ao fato de fazerem parte ou não de coalizões pró ou contra o governo. ${ }^{5}$

Diante do exposto o presente artigo busca saber qual o peso da variável ideologia em tempos atuais a partir da análise de votações nominais de leis com teor ideológico, ou seja, que se espera que dividam os deputados segundo o posicionamento ideológico de seus partidos. No trabalho em questão serão objeto de análise "novos" temas que se fazem presentes no debate contemporâneo, partindo da premissa de que questões econômicas perdem espaço e dão lugar a uma agenda pós-materialista. "Novos" temas se fazem presentes no debate contemporâneo e relacionados à possibilidade de ampliação da qualidade de vida, deixando em segundo plano antagonismos em relação ao grau de interferência estatal em relação à economia e área social. ${ }^{6}$ Esta tendência é aplicável ao Brasil e onde a aderência a valores pós-materialistas em tempos recentes pode ser

\footnotetext{
4 POWER, T. J.; ZUCCO JR., C. Estimating ideology of Brazilian legislative parties, 1990-2005: a research communication. Latin American Research Review, v.44, n.1, 2009, p.218-246.

5 CARREIRÃO, Y. de S. O sistema partidário brasileiro: um debate com a literatura recente. Revista Brasileira de Ciência Política, n. 14. Brasília, mai.-ago. 2014, p. 255, 295.
}

${ }^{6}$ INGLEHART, R. The silent revolution. Princeton: Princeton University Press, 1977. 
SCHEEFFER, Fernando. Esquerda, direita e "novos" temas na Câmara dos Deputados. Revista Eletrônica Direito e Política, Programa de Pós-Graduação Stricto Sensu em Ciência Jurídica da UNIVALI, Itajaí, v.12, n.3, $3^{\circ}$ quadrimestre de 2017. Disponível em: www.univali.br/direitoepolitica - ISSN 1980-7791

constatada com suas peculiaridades. ${ }^{7}$ Desta forma, talvez se possa afirmar que, em se tratando de questões econômicas e sociais, talvez haja poucas divergências entre os partidos, diferente de outros temas que estariam relacionados à ampliação do bem-estar, em tempos recentes, e que denotariam novas clivagens, frente a um cenário multifacetado e complexo.

Apresentados os procedimentos metodológicos da pesquisa o artigo é iniciado com uma discussão sobre o significado da terminologia esquerda e direita, sobretudo sobre as novas clivagens que parecem estar pautando o debate político recente. Feito isso parte-se para a análise e discussão dos resultados. Em todos os temas será feita anteriormente uma breve contextualização da lei em questão para em um segundo momento ser ressaltado o que deveria ocorrer levando em consideração divergências político-ideológicas expostas na fundamentação teórica.

\section{PROCEDIMENTOS METODOLÓGICOS}

O banco de dados utilizado consiste nas informações disponibilizadas pelo site da Câmara dos Deputados e de responsabilidade do Centro de Documentação e Informação (CEDI). O período objeto de análise foi o governo Dilma (2011-2015). Tendo acesso à base de dados do Núcleo de Estudos sobre o Congresso (NECON), com todas as votações nominais realizadas na Câmara dos Deputados no período, foram escolhidas aquelas notadamente ideológicas, isto é, aquelas que foi possível supor um comportamento esperado dos partidos de esquerda e direita a partir do que foi desenvolvido na base teórica. Preferencialmente, foram privilegiadas partes específicas das leis, partes menos consensuais e alvo de maiores divergências, visto que os textos finais, em muitos casos, são resultado de uma série de concessões e acordos.

Verificado o comportamento parlamentar por meio do voto, foi relacionado este com o espectro ideológico do partido a que pertence. Será utilizada aqui a realizada para a elaboração do livro "Coligações partidárias na nova democracia brasileira: perfis e tendências". Trata-se de uma classificação realizada justamente buscando

7 RIBEIRO, E. A. Valores pós-materialistas e cultura política no Brasil. Maringá: Eduem, 2011. 
SCHEEFFER, Fernando. Esquerda, direita e "novos" temas na Câmara dos Deputados. Revista Eletrônica Direito e Política, Programa de Pós-Graduação Stricto Sensu em Ciência Jurídica da UNIVALI, Itajaí, v.12, n.3, $3^{0}$ quadrimestre de 2017. Disponível em: www.univali.br/direitoepolitica - ISSN 1980-7791

uma padronização a ser utilizada por diversos pesquisadores envolvidos no projeto patrocinado pela Fundação Konrad-Adenauer, que resultou no livro mencionado. ${ }^{8}$ Para os partidos novos foi levada em consideração a classificação realizada por especialistas ligados a um novo projeto semelhante, novamente patrocinado pela fundação, visando a edição de um livro com dados mais atualizados sobre coligações. Como não houve consenso entre os autores, utilizou-se a classificação feita pela maioria deles. Para a verificação dos partidos pertences às coalizões de governo nos períodos da votação foi utilizado o banco de dados legislativos do Centro Brasileiro de Análise e Planejamento (CEBRAP/USP).

As leis analisadas foram o Código Florestal Brasileiro (PL 1876/1999), a que dispunha sobre a rotulagem dos transgênicos (PL 4148/2008), cotas para concurso público ( $\mathrm{PL}$ 6738/2013), criminalização de práticas indígenas nocivas (PL 1057/2007), Plano Nacional de Participação Social (PDC 1491/2014), identidade de gênero (PL 7699/2009), cotas para mulheres no legislativo (PL 7699/2006) e criação da Comissão Nacional da Verdade (PL 7376/2010). Em cada uma das leis foi feita uma análise de regressão logística que estima a chance de ocorrência de determinado evento ocorrer ou não. "[...] é um método de predição multivariada, que é empregado quando as variáveis independentes são utilizadas na explicação do resultado categórico (variável dependente), frequentemente dicotômico". ${ }^{9} \mathrm{~A}$ variável dependente, nesse caso, seria o voto (sim e não) e as variáveis independentes ideologia (direita/centro/esquerda) e situação (governo/oposição), ambas categóricas.

\section{ESQUERDA E DIREITA: VELHAS IDEOLOGIAS CEDEM LUGAR A NOVAS?}

A visão hegemônica é a de que mesmo a ascensão capitalista e a derrocada da antiga URSS e dos regimes socialistas não são suficientes para se afirmar que os termos esquerda e direita estejam ultrapassados e não tenham mais significação. A dicotomia esquerda-direita vai além da bipolaridade capitalismo-socialismo que

\footnotetext{
${ }^{8}$ KRAUSE, S.; DANTAS, H.; MIGUEL, L. F. (orgs.) Coligações partidárias na nova democracia brasileira: perfis e tendências. Rio de Janeiro: Konrad-Adenauer, 2010.

9 RIBAS, J. R.; VIEIRA, P. R. da C. Análise multivariada com o uso do SPSS. Rio de Janeiro: Ciência Moderna, 2011. p. 195.
} 
SCHEEFFER, Fernando. Esquerda, direita e "novos" temas na Câmara dos Deputados. Revista Eletrônica Direito e Política, Programa de Pós-Graduação Stricto Sensu em Ciência Jurídica da UNIVALI, Itajaí, v.12, n.3, $3^{\circ}$ quadrimestre de 2017. Disponível em: www.univali.br/direitoepolitica - ISSN 1980-7791

orientou toda a ordem política mundial durante anos. Os princípios típicos da esquerda e da direita não acabam com o fim da bipolaridade. ${ }^{10} \mathrm{Um}$ dos defensores mais conhecidos da crença de que é necessário atualizar o significado desta terminologia é Norberto Bobbio. Segundo ele a igualdade para a esquerda deve ser priorizada, em detrimento da liberdade (que para a direita deve ser conservada, mantendo-se as desigualdades entre os homens, tidas como naturais). ${ }^{11} \mathrm{Em}$ se tratando de distinções clássicas entre esquerda e direita essa distinção é central. Tratam-se de divergências em relação à quanto que o Estado deve intervir social e economicamente. Fica a pergunta: Qual o alcance dessa dimensão hoje? Qual o grau de independência dos novos temas ou em que medida são adornos das ideologias anfitriãs? A reposta a essas questões se faz pertinente dados os novos temas que dividem a opinião pública e os agentes políticos em tempos recentes.

O momento diferenciado que nos deparamos está relacionado à transição das sociedades industriais para as pós-industriais. As divisões de classe deixam de ser claras, enquanto que outras questões passam a estruturar o processo político, sistema partidário e o próprio debate ideológico. As questões materiais tornam-se secundárias em condições mais prósperas e há a emergência de questões pósmateriais. Se fazem presentes temas como igualdade entre os sexos, paz mundial, harmonia racial, proteção ambiental e direitos dos animais. ${ }^{12} \mathrm{O}$ célebre defensor do chamado pós-materialismo é Ronald Inglehart. Segundo ele haveria após a segunda metade do século XX uma lenta e gradual mudança de um amplo espectro de valores humanos. Questões econômicas perdem espaço e dão lugar a um esforço diferenciado para maximizar o bem-estar no mundo contemporâneo. Em suma, depois de alcançada a segurança material, dá-se espaço a questões como qualidade de vida em seu sentido amplo, preservação ambiental, possibilidade de auto expressão, dentre outras. Uma das possibilidades de interpretação é que, se há uma substituição de valores materialistas por pós-materialistas, esta seria uma

\footnotetext{
10 FREITAS, M. A. A esquerda brasileira em tempos neoliberais. Revista de Ciência Política, Rio de Janeiro, v. 17, 2004.

11 BOBBIO, N. Direita e Esquerda: razões e significados de uma distinção política. São Paulo: Editora da UNESP, 1995.

12 HEYWOOD, A. Ideologias políticas: do liberalismo ao fascismo. São Paulo: Ática, $2010 a$.
} 
SCHEEFFER, Fernando. Esquerda, direita e "novos" temas na Câmara dos Deputados. Revista Eletrônica Direito e Política, Programa de Pós-Graduação Stricto Sensu em Ciência Jurídica da UNIVALI, Itajaí, v.12, n.3, $3^{\circ}$ quadrimestre de 2017. Disponível em: www.univali.br/direitoepolitica - ISSN 1980-7791

outra dimensão, sem necessariamente estar relacionada à tradicional dicotomia esquerda e direita. ${ }^{13}$ Por outro lado é possível falar em "velhos" e "novos" temas, isto é, ambos relacionados à terminologia esquerda e direita. ${ }^{14}$ Esta hipótese é a que é testada neste trabalho.

Heywood busca apresentar as principais ideologias clássicas assim como os novos temas que fazem parte do debate político-ideológico. As "novas ideologias", segundo ele, diferem das "clássicas" por várias razões. Em primeiro lugar, houve uma mudança de enfoque da economia para a cultura. Ideologias como o liberalismo e o socialismo, por exemplo, se ocupavam primordialmente de questões de organização econômica. As "novas" ideologias, diferentemente, estão mais interessadas na cultura do que na economia. Valores, crenças e estilos de vida das pessoas se sobrepõem à busca por conforto econômico ou justiça social: o termo classe social dá lugar à identidade. As novas ideologias enfatizam fatores como gênero, cultura, etnia. Podem ser consideradas novas, pois deram notoriedade sem precedentes a certas áreas do debate ideológico recente. ${ }^{15}$ Serão priorizados os temas que são objeto deste trabalho: meio ambiente, multiculturalismo, participação, conservadorismo e feminismo. Na sequência são expostas de forma simplificada divergências teórico-conceituais que a princípio deveriam acarretar comportamentos distintos de atores políticos de esquerda e direita.

O grande dilema político-ideológico no que diz respeito ao enfrentamento da questão ambiental passa pelas respostas a algumas perguntas como: quais as melhores instituições para a regulação do uso e acesso aos recursos naturais? É possível conciliar intervenção do poder público e autorregulação? Mecanismos de

13 TAROUCO, G. Brazilian parties according to their manifestos: political identity and programmatic emphases. Brazilian Political Science Review, São Paulo, v. 5, n. 1, p. 54-76, 2011. Disponível em: <http://www.bpsr.org.br/index.php/bpsr/article/view/114/105> Acesso em: 11 nov. 2013.

TAROUCO, G. da S.; MADEIRA, R. M. Partidos, programas e o debate sobre esquerda e direita no Brasil. Rev. Sociol. Polit. Curitiba, v. 21, n. 45, mar. 2013.

${ }^{14}$ HEYWOOD, A. Ideologias políticas: do feminismo ao multiculturalismo. São Paulo: 2010b.

ROSAS, J. C.; FERREIRA, A. R (orgs.) Left and right: the great dichotomy revisited. New Castle: Cambridge Scholars Publishing, 2013.

${ }^{15}$ Segundo ele as mais significativas são o feminismo, o ecologismo, o fundamentalismo religioso e o multiculturalismo. 
SCHEEFFER, Fernando. Esquerda, direita e "novos" temas na Câmara dos Deputados. Revista Eletrônica Direito e Política, Programa de Pós-Graduação Stricto Sensu em Ciência Jurídica da UNIVALI, Itajaí, v.12, n.3, $3^{\circ}$ quadrimestre de 2017. Disponível em: www.univali.br/direitoepolitica - ISSN 1980-7791

mercado podem auxiliar o controle da exploração dos recursos naturais? O modo de responder tais questões denota divergências importantes em relação ao papel do Estado na proteção ao meio ambiente e na regulação do uso dos recursos naturais. A esquerda defende a regulação do Estado como solução para dar conta da contradição entre os interesses individuais e os interesses coletivos. A direita por sua vez acredita que os mecanismos de mercado poderiam fazer o enfrentamento aos problemas sociais. Os inúmeros certificados ambientais ou selos verdes seriam exemplos de mecanismos privados de regulação ou autorregulação. ${ }^{16}$ Por esse viés, a política ambiental estatal é percebida pelos interesses privados como um empecilho. São custosas e uma ameaça ao crescimento econômico. ${ }^{17}$ Nota-se que a o enfrentamento da questão ambiental, longe de ser um tema independente, tem relação direta a divergências sobre o papel do Estado e o grau esperado de interferência econômica e social. ${ }^{18}$

Um dos "novos" temas mais proeminentes é o multiculturalismo. Para Heywood agrupa divergências em torno das consequências da crescente diversidade cultural e a possibilidade da diversidade dentro da unidade. Vale destacar que há modelos multiculturais diferenciados e com contornos eminentemente políticos. ${ }^{19}$ É notória a distinção entre esquerda e direita no que diz respeito ao multiculturalismo. A esquerda, em nome da defesa dos direitos multiculturais ou das minorias, defenderia as ações afirmativas e uma discriminação "positiva" para assegurar igualdade. Recusa a premissa de que a diversidade gera conflito ou instabilidade. A direita, pautada nos princípios do liberalismo político, vê o multiculturalismo e a diversidade com ressalvas, pautada na crença central de que valores compartilhados e uma cultura comum são pré-requisitos necessários para o bom andamento da sociedade. Por uma perspectiva liberal as políticas de ações

${ }^{16}$ CUNHA, S. B. da.; GUERRA, A. J. T. (orgs.) A questão ambiental: diferentes abordagens. Rio de Janeiro: Bertrand Brasil, 2003.

17 SACHS, I. Espaços, tempos e estratégias de desenvolvimento. São Paulo: Vértice, 1986.

18 No debate sobre o Código Florestal Brasileiros, assim como na discussão sobre os transgênicos, no Congresso Nacional destacam-se dois grupos, a princípio com interesses antagônicos. Os ruralistas se demonstrariam comprometidos com a atividade produtiva e os ambientalistas em tese deveriam se colocar como defensores ferrenhos da proteção ambiental.

19 FERNANDES, J. P. T. A ideologia do multiculturalismo. Disponível em:<http://recil.grupolusofona.pt/bitstream/handle/10437/4286/a_ideologia_do_multiculturalismo .pdf?sequence=1> Acesso em: 17 mai. 2016 . 
SCHEEFFER, Fernando. Esquerda, direita e "novos" temas na Câmara dos Deputados. Revista Eletrônica Direito e Política, Programa de Pós-Graduação Stricto Sensu em Ciência Jurídica da UNIVALI, Itajaí, v.12, n.3, $3^{\circ}$ quadrimestre de 2017. Disponível em: www.univali.br/direitoepolitica - ISSN 1980-7791

afirmativas e o sistema de cotas criam privilégios considerados maléficos. Direitos universais seriam mais democráticos na medida em que atendem indiscriminadamente às necessidades e aos interesses de todos os cidadãos sem qualquer tipo de distinção. Diferentemente, para os defensores do multiculturalismo, a igualdade política significa igualdade de acesso, ou ainda, tratamento especial para quem necessita de direitos especiais. ${ }^{20}$

No Brasil em particular, um conteúdo importante vinculado às categorias esquerda e direita é o da participação social, sobretudo pelo vínculo da direita com a ditadura militar e o enfrentamento ao regime por parte da esquerda. ${ }^{21} \mathrm{~A}$ partir de uma discussão mais ampla, no que tange ao ideário de direita, a democracia é tornada compatível com as exigências do liberalismo. A democracia liberal se desvincula do conceito originário de democracia ao defender o direito ao voto, considerado uma forma privilegiada de participação política. Haveria, então, uma defesa da democracia representativa com todas as suas nuances e aversão a estratégicas consideradas "subversivas". A esquerda por sua vez passa, sobretudo após o fim dos regimes ditatoriais e com o início do processo de (re)democratização, a ver a democracia como um valor. A busca por ampliação de espaços de participação passar a fazer parte do rol de lutas a serem travadas. A defesa da democracia passa a ser um carro-chefe para a esquerda, sobretudo na sua vertente participativa. ${ }^{22}$

Em relação ao conservadorismo, embora trate-se de uma corrente de pensamento surgida na Inglaterra no final do século XVIII e tem como um dos principais

20 SACCHET, T. Representação política, representação de grupos e política de cotas: perspectivas e contendas feministas. Rev. Estud. Fem., Florianópolis, v. 20, n. 2, p. 399-431, Ago. 2012 . Disponível em: <http://www.scielo.br/scielo.php?script=sci_arttext\&pid=S0104026X2012000200004\&lng=en\&nrm=iso> Acesso em: 13 jun. 2016.

21 RODRIGUES, L. M. Quem é quem na Constituinte: uma análise sociopolítica dos partidos e deputados. São Paulo: OESP-Maltese, 1987. O autor enfatiza o que se convencionou chamar de "direita envergonhada". Grupos políticos e pessoas adeptas de um ideário de direita teriam dificuldade de se autodeclarar como tal visto o caráter negativo da ditadura militar na história recente do Brasil.

22 SCAVO, D. G.; BEZERRA, E. M. A crise da democracia liberal e os novos movimentos democráticos. Passa a defender a "radicalização da tradição democrática moderna", isto é, a buscar a democratização da democracia liberal. 
SCHEEFFER, Fernando. Esquerda, direita e "novos" temas na Câmara dos Deputados. Revista Eletrônica Direito e Política, Programa de Pós-Graduação Stricto Sensu em Ciência Jurídica da UNIVALI, Itajaí, v.12, n.3, $3^{\circ}$ quadrimestre de 2017. Disponível em: www.univali.br/direitoepolitica - ISSN 1980-7791

representantes Edmund Burke, o grau em que temas impactados pelo mesmo passam a fazer parte do debate político justifica chama-lo de um novo tema, sobretudo o que se convencionou chamar de "neoconservadorismo". Para Quadros (2014) trata-se de sua mais recente manifestação e com origem em terras norteamericanas. Suas ações mais consistentes dos considerados neoconservadores ficam evidentes nas publicações do National Review ${ }^{23}$, movimento que ganha força na década de 1970. Tem foco claro no anticomunismo e principalmente é tradicional nos temas ligados à moralidade. A ênfase maior está nos costumes e por estratégia ou convicção potencializa demandas da direita religiosa. 0 conservador busca preservar o que se tem ao acreditar que as mudanças em determinadas esferas provocam perdas inevitáveis e que dificilmente poderão ser substituídas. "O que faz de alguém um conservador é a forma de lidar com a tradição e com a mudança no contexto da comunidade humana em desenvolvimento". ${ }^{24}$

Em caráter ilustrativo, para a direita a homossexualidade não é bem vista já que abala os valores que regem a vida social. Para a esquerda, ao contrário, os direitos dos homossexuais devem ser reconhecidos, visto que suas opções sexuais não causam danos a terceiros. São temas vinculados a esse ideário ainda a não aceitação do aborto e da legalização da maconha. Falar em liberalismo enquanto ideologia de direita, por exemplo, só faz sentido em se tratando da não intervenção social e econômica do Estado o que, infringiria a liberdade individual. Quando falamos em liberalismo em termos não econômicos a correlação é invertida, estamos falando de uma defesa da esquerda. ${ }^{25}$

[...] a nova direita é como um casamento entre duas tradições ideológicas aparentemente antagônicas. A primeira delas é a economia liberal clássica (crítica ao governo "grande" e à intervenção social e econômica). Ela é chamada de nova direita liberal, ou neoliberalismo. O segundo elemento da

23 Revista fundada em 1955 e desde então se consolidou como importante instrumento de disseminação das ideias conservadoras nos Estados Unidos.

24 KOYSIS, D. T. Visões e ilusões políticas: uma análise e crítica cristã das ideologias contemporâneas. São Paulo: Vida Nova, 2014. p. 92.

25 ALMEIDA, A. C. Ideologia e comportamento eleitoral: evidências de que a ideologia não é importante para explicar o voto. Trabalho apresentado no $25^{\circ}$ Encontro Anual da ANPOCS, CaxambuMG, 2001. 
SCHEEFFER, Fernando. Esquerda, direita e "novos" temas na Câmara dos Deputados. Revista Eletrônica Direito e Política, Programa de Pós-Graduação Stricto Sensu em Ciência Jurídica da UNIVALI, Itajaí, v.12, n.3, $3^{\circ}$ quadrimestre de 2017. Disponível em: www.univali.br/direitoepolitica - ISSN 1980-7791

nova direita é a teoria social conservadora tradicional que enfatiza sobretudo a defesa da ordem, da autoridade e da disciplina. Esta é chamada de nova direita conservadora, ou neoconservadorismo. ${ }^{26}$

Dito de outra forma a esquerda de hoje exibe claramente uma combinação entre coletivismo e individualismo moral enquanto a direita um liberalismo conservador. ${ }^{27}$

Outra luta recente encampada por vários movimentos sociais é o feminismo. 0 feminismo, movimento "inventado" no século XX com o intuito de fortalecer o papel social da mulher, parte de dois princípios básicos: o de que as mulheres vivem em desvantagem por serem mulheres, e o segundo, decorrente do primeiro, o de que essa desvantagem pode e deve ser abolida. Pauta da esquerda, as relações de gênero constituem um eixo estruturante das desigualdades. 0 feminismo faz o resgate das relações na esfera privada, se debruça sobre as relações de poder tanto quanto as relações de trabalho ou relações políticas institucionalizadas. Esse movimento trás para a agenda política a importância de se atuar no sentido de minorar e superar as desigualdades de gênero e que, no fim das contas, acabam por seres responsáveis por impedir o pleno desenvolvimento e realização das capacidades e potencialidades das mulheres. ${ }^{28}$ A direita tenderia a considerar natural e inevitável o patriarcado. Defende um homem "público" e uma mulher "particular". Dito de outra forma, as mulheres nasceram para ser esposas e mães. Na melhor das hipóteses, segundo ele, os conservadores argumentam que apoiam a igualdade social visto que as responsabilidades familiares são tão importantes quanto os deveres públicos dos homens. Seriam as mulheres então, "iguais, mas diferentes". Como se pode notar parece fazer sentido supor que o feminismo está relacionado ao conservadorismo

\footnotetext{
26 HEYWOOD, A. Ideologias políticas: do liberalismo ao fascismo. p. 97.

27 LEVIN, Y. The great debate: Edmund Burke, Thomas Paine, and the birth of right and left. New York: Basic Books, 2014.

${ }^{28}$ RODRIGUES, A. Feminismo e nova esquerda: um diálogo em construção. In: ALMEIDA, F. I. de. (org.). O que é ser esquerda hoje? Rio de Janeiro: Contraponto, 2013.
} 
SCHEEFFER, Fernando. Esquerda, direita e "novos" temas na Câmara dos Deputados. Revista Eletrônica Direito e Política, Programa de Pós-Graduação Stricto Sensu em Ciência Jurídica da UNIVALI, Itajaí, v.12, n.3, $3^{\circ}$ quadrimestre de 2017. Disponível em: www.univali.br/direitoepolitica - ISSN 1980-7791

levando em consideração o apego à tradição como marca de uma distinção "natural" entre homens e mulheres. ${ }^{29}$

Deve-se ter cuidado em utilizar as categorias esquerda e direita visto que as mesmas dizem respeito a temas em voga em determinada época, ou seja, não têm um sentido único e por isso não podem ser universalmente aceitas. ${ }^{30} \mathrm{O}$ fato é que muitas são as clivagens possíveis em tempos atuais. Independentemente de serem de ordem social, política ou cultural, o que não se pode negligenciar é sua perspectiva dinâmica. Novas questões e preocupações podem dar vida a clivagens dormentes. Isso pode justificar a sobrevida da terminologia esquerda e direita hoje e, além do mais, seu fortalecimento ao invés da previsão recorrente de um término eminente.

\section{ANÁLISE E DISCUSSÃO DOS RESULTADOS}

Estando claros os procedimentos metodológicos da pesquisa e exposto brevemente $\mathrm{o}$ arcabouço teórico que a princípio deveria acarretar distintos comportamentos dos parlamentares em plenário em relação a novos temas, passa-se à análise das leis a fim de verificar o peso da variável ideologia na Câmara dos Deputados.

\subsection{CÓDIGO FLORESTAL BRASILEIRO (PL 1876/1999)}

A discussão da atualização do Código Florestal Brasileiro passa a ocorrer a partir de 1999 por meio do projeto de lei 1876/1999. Foco específico desta análise, no dia 24 de maio de 2011 é colocada em votação a polêmica emenda 164 de autoria de Paulo Piau (PMDB/MG). Entre outras coisas a emenda regulariza a situação de ocupações ilegais em áreas de preservação permanente (APPs), como beira de rios, topos de morros e encostas até julho de 2008. Tem como principal objetivo consolidar as áreas de produção agrícola, de pecuária e outras atividades rurais existentes em APPs no país. Cabe ainda ao poder público (governo federal e dos estados) determinar quais áreas devem ser reflorestadas. A atribuição desse

\footnotetext{
${ }^{29}$ HEYWOOD, A. Ideologias políticas: do feminismo ao multiculturalismo. São Paulo: 2010b.

30 KOYSIS, D. T. Visões e ilusões políticas: uma análise e crítica cristã das ideologias contemporâneas. São Paulo: Vida Nova, 2014.
} 
SCHEEFFER, Fernando. Esquerda, direita e "novos" temas na Câmara dos Deputados. Revista Eletrônica Direito e Política, Programa de Pós-Graduação Stricto Sensu em Ciência Jurídica da UNIVALI, Itajaí, v.12, n.3, $3^{\circ}$ quadrimestre de 2017. Disponível em: www.univali.br/direitoepolitica - ISSN 1980-7791

encargo aos órgãos estaduais é criticada visto que flexibiliza a legislação ambiental e deixa à mercê do poder local as definições quanto ao tema. ${ }^{31}$ Para a votação em plenário realizada no dia 24 de maio de 2011 na Câmara dos Deputados é considerado um voto esperado da esquerda a recusa do referido projeto (não), ao passo que a direita deveria acatar ao aceite da emenda 164 (sim). A Tabela 1 apresenta uma síntese dos resultados da regressão logística realizada.

Tabela 1 - Voto "não" emenda 164: análise de regressão logística

\begin{tabular}{ccccccc}
\hline Variável & B & S.E. & Wald & df & Sig. & Exp(B) \\
\hline Ideologia & & & 93,711 & 2 &, 000 & \\
Ideologia(D) & $-1,792$ &, 263 & 46,297 & 1 &, 000 &, 167 \\
Ideologia(C) & $-4,434$ &, 540 & 67,367 & 1 &, 000 &, 012 \\
Governo & 1,014 &, 270 & 14,106 & 1 &, 000 & 2,757 \\
Constante &, 342 &, 272 & 1,577 & 1 &, 209 & 1,407 \\
$\begin{array}{l}\mathrm{N}=414 ; \text { Chi-quadrado }=210,957 ; \mathrm{g.I}=3 ; \text { Sig. }=0,00 ; \mathrm{R}^{2} \text { (Nagelkerke) }=0,502 \\
\% \text { acerto total = 20,2\% }\end{array}$
\end{tabular}

Os dados abaixo da tabela indicam que o modelo é satisfatório. Todas as variáveis são estatisticamente significativas e verificada a estatística de Wald, os coeficientes maiores demonstram o maior peso da variável ideologia. A chance de um parlamentar da coalizão governista votar "não" representa quase 3 vezes a chance de um parlamentar da oposição. Já no que tange à variável ideologia, a chance de um parlamentar de centro votar "não" equivale a um pouco mais de $1 \%$ da chance de um parlamentar de esquerda. Já a chance de um de direita equivale a cerca de $16 \%$ da chance de um de esquerda. Os dados da regressão logística confirmam o peso da ideologia, sobretudo o vínculo da direita ao "sim" e da esquerda ao "não". Curioso é o posicionamento do centro (PMDB e PSDB) que aderiu ao "sim" muito mais que os parlamentares de direita.

31 CAMARgO, R. Conheça a emenda vilã do Código Florestal. 28 mai. 2011. Disponível em: <http://congressoemfoco.uol.com.br/codigo-florestal/conheca-a-emenda-vila-do-codigo-florestal/> Acesso em: 05 fev. 2015. 
SCHEEFFER, Fernando. Esquerda, direita e "novos" temas na Câmara dos Deputados. Revista Eletrônica Direito e Política, Programa de Pós-Graduação Stricto Sensu em Ciência Jurídica da UNIVALI, Itajaí, v.12, n.3, $3^{0}$ quadrimestre de 2017. Disponível em: www.univali.br/direitoepolitica - ISSN 1980-7791

\subsection{ROTULAGEM DE TRANSGÊNICOS (PL 4148/2008)}

O Projeto de Lei n $4148 / 2008$ trata da informação da natureza transgênica dos alimentos nos rótulos destinados ao consumo humano. Prevê que o aviso aos consumidores somente será obrigatório nas embalagens dos alimentos que apresentarem presença de organismos transgênicos superior a 1\%. Também não é mais necessário indicar a espécie doadora do gene bem como indicação da presença de DNA ou proteína resultante da modificação genética, além de ser realizada a rotulagem de ingredientes e alimentos produzidos a partir de animais alimentados com ração com ingredientes transgênicos. ${ }^{32}$

A mudança das regras na rotulagem deveria em princípio dividir a esquerda e a direita visto que o afrouxamento das regras atenderiam aos anseios do agronegócio e da produção em grande escala. Já os ambientalistas hesitariam em aceitar o dispositivo que a longo prazo implicaria em aumento dramático do uso dos agrotóxicos e perda ou alteração do patrimônio genético de plantas e sementes. ${ }^{33}$ Para testar essa premissa, foi analisada a votação da subemenda substitutiva global oferecida pelo relator da Comissão de Desenvolvimento Econômico, Indústria e Comércio (CDEIC) realizada em 28/04/2015. O voto "sim" implicaria no aceite da mudança e seria o voto esperado da direita, enquanto o rejeite seria o que se esperaria da esquerda. Em seguida são apresentados os dados da regressão logística.

32 CÂMARA DOS DEPUTADOS. Projeto de lei $\mathbf{n}^{\circ} \mathbf{4 1 4 8}$ de $\mathbf{2 0 0 8}$. Disponível em: <http://www.camara.gov.br/proposicoesWeb/prop_mostrarintegra;jsessionid=4477655DB192D29 65AF0E7CFA2C5C9CD. proposicoesWeb2?codteor $=605180 \&$ filename $=P L+4148 / 2008>$ Acesso em: 03 set. $2015 a$.

33 O uso indiscriminado de agrotóxicos está diretamente associado ao aumento dos transgênicos no campo uma vez que o cultivo de sementes geneticamente modificadas exigem o uso de grandes quantidades destes produtos. 
SCHEEFFER, Fernando. Esquerda, direita e "novos" temas na Câmara dos Deputados. Revista Eletrônica Direito e Política, Programa de Pós-Graduação Stricto Sensu em Ciência Jurídica da UNIVALI, Itajaí, v.12, n.3, $3^{\circ}$ quadrimestre de 2017. Disponível em: www.univali.br/direitoepolitica - ISSN 1980-7791

Tabela 2 - Voto "não" rotulagem de transgênicos: análise de regressão logística

\begin{tabular}{ccccccc}
\hline Variável & B & S.E. & Wald & df & Sig. & Exp(B) \\
\hline Ideologia & & & 149,721 & 2 &, 000 & \\
Ideologia(D) & $-3,647$ &, 331 & 121,359 & 1 &, 000 &, 026 \\
Ideologia(C) & $-4,478$ &, 556 & 64,875 & 1 &, 000 &, 011 \\
Governo &,- 979 &, 323 & 9,186 & 1 &, 002 & 2,661 \\
Constante &, 630 &, 252 & 6,230 & 1 &, 013 & 1,877 \\
\hline
\end{tabular}

$\mathrm{N}=455 ;$ Chi-quadrado $=241,285 ; \mathrm{g} . \mathrm{I}=3 ;$ Sig. $=0,000 ; \mathrm{R}^{2}($ Nagelkerke $)=0,585$ $\%$ acerto total $=17 \%$

A partir da análise de regressão logística, um parlamentar governista teria 2,6 vezes a chance de votar "não" comparado a um da oposição. Já ser de direita implicaria em $2,6 \%$ da chance comparado a um de esquerda, ser de centro cerca de $1 \%$. Os valores da estatística de Wald destacam o maior peso da variável ideologia como esperado. O modelo se demonstrou significativo, com um percentual de acerto de $17 \%$.

\subsection{COTAS PARA CONCURSO PÚBLICO (PL 6738/2013)}

O Projeto de Lei 6738/13, do poder Executivo, reserva $20 \%$ das vagas em concursos públicos a candidatos negros que assim se declararem no ato da inscrição. A medida tem duração de dez anos e se refere a concursos públicos da administração direta e indireta como autarquias, fundações públicas, empresas públicas e sociedades de economia mistas controladas pela União. ${ }^{34}$

A partir dos elementos sintetizados na fundamentação teórica espera-se que os parlamentares de esquerda sejam favoráveis ao referido projeto, enquanto os de direita o rejeitem. Embora haja consenso em falar que as cotas se caracterizam

${ }^{34}$ CÂMARA DOS DEPUTADOS. Aprovado projeto que reserva $\mathbf{2 0} \%$ das vagas em concursos federais para negros. 26 mar. 2014. Disponível em: <http://www2.camara.leg.br/camaranoticias/noticias/ADMINISTRACAO-PUBLICA/464662APROVADO-PROJETO-QUE-RESERVA-20-DAS-VAGAS-EM-CONCURSOS-FEDERAIS-PARANEGROS.html> Acesso em: 17 ago. 2015. 
SCHEEFFER, Fernando. Esquerda, direita e "novos" temas na Câmara dos Deputados. Revista Eletrônica Direito e Política, Programa de Pós-Graduação Stricto Sensu em Ciência Jurídica da UNIVALI, Itajaí, v.12, n.3, $3^{\circ}$ quadrimestre de 2017. Disponível em: www.univali.br/direitoepolitica - ISSN 1980-7791

como uma discriminação, para a esquerda trata-se de uma discriminação positiva, necessária para enfrentar desigualdades históricas. Para a direita medidas universalistas seriam mais interessantes e não reforçariam práticas de privilegiamento. Objeto de análise é a votação realizada no dia 26/03/2014.

\section{Tabela 3 - Voto "não" cotas para concurso público: análise de regressão logística}

\begin{tabular}{ccccccc}
\hline Variável & B & S.E. & Wald & df & Sig. & Exp(B) \\
\hline Ideologia & & & 5,682 & 2 &, 058 & \\
Ideologia(D) & 1,254 &, 529 & 5,628 & 1 &, 018 & 3,505 \\
Ideologia(C) & 1,052 &, 580 & 3,289 & 1 &, 070 & 2,863 \\
Governo &,- 654 &, 385 & 2,888 & 1 &, 089 &, 520 \\
Constante & $-2,750$ &, 512 & 28,844 & 1 &, 000 &, 064 \\
$\begin{array}{l}\mathrm{N}=350 ; \text { Chi-quadrado }=13,528 ; \text { g.l }=3 \text {; Sig. }=0,004 ; \mathrm{R}^{2} \text { (Nagelkerke) }=0,078 \\
\% \text { acerto total = 0\% }\end{array}$
\end{tabular}

Os dados da regressão logística apontam que a chance de um parlamentar de direita votar "não" é 3,5 vezes a chance de um parlamentar de esquerda. As outras categorias não se demonstram significativas (valor Sig.). O modelo se demonstra ineficaz a partir das variáveis escolhidas, o que fica evidente também pela porcentagem de acerto das respostas. Desta forma, tudo indica que não há uma relação entre as variáveis independentes ideologia e situação ou esta se dá de forma aleatória o que não permite se fazer previsões como esperado.

\subsection{CRIMINALIZAÇÃO DE PRÁtICAS INDÍGENAS NOCIVAS 1057/2007)}

O projeto de lei $n^{\circ} 1057 / 2007$, de autoria do deputado Henrique Afonso (PT/AC), dispõe sobre o combate a práticas tradicionais nocivas e à proteção dos direitos fundamentais de crianças indígenas. Consideram-se nocivas as práticas tradicionais que atentem contra a vida e a integridade físico-psíquica tais como: abuso sexual, maus-tratos e principalmente homicídios de recém nascidos independente da justificativa como nascimento com algum tipo de deficiência física 
SCHEEFFER, Fernando. Esquerda, direita e "novos" temas na Câmara dos Deputados. Revista Eletrônica Direito e Política, Programa de Pós-Graduação Stricto Sensu em Ciência Jurídica da UNIVALI, Itajaí, v.12, n.3, $3^{\circ}$ quadrimestre de 2017. Disponível em: www.univali.br/direitoepolitica - ISSN 1980-7791

e/ou mental. Esse projeto ficou conhecido como "Lei Muwaji", em homenagem a uma mãe da tribo dos suruwahas que se rebelou contra a tradição de sua tribo e salvou a vida da filha que seria morta por ter nascido deficiente. ${ }^{35}$

De forma bastante polêmica é colocada em votação no dia 26/08/2015 a subemenda substitutiva global que teve como relator o deputado Marcos Rogério (PDT/RO). Como exposto em capítulo teórico, a expectativa é que a esquerda seja mais contrária dada a sua afinidade com o multiculturalismo. A direita, diferentemente, em nome da universalidade seria majoritariamente favorável.

Tabela 4 - Voto "não" criminalização de práticas indígenas nocivas: análise de regressão logística

\begin{tabular}{ccccccc}
\hline Variável & B & S.E. & Wald & df & Sig. & Exp(B) \\
\hline Ideologia & & & 89,046 & 2 &, 000 & \\
Ideologia(D) & $-3,011$ &, 360 & 69,907 & 1 &, 000 &, 049 \\
Ideologia(C) & $-4,109$ &, 742 & 30,669 & 1 &, 000 &, 016 \\
Governo & 1,372 &, 332 & 17,064 & 1 &, 000 & 3,941 \\
Constante &,- 792 &, 268 & 8,734 & 1 &, 003 &, 453 \\
\hline
\end{tabular}

$\mathrm{N}=445 ;$ Chi-quadrado $=146,699 ; \mathrm{g} . \mathrm{I}=3 ;$ Sig. $=0,000 ; \mathrm{R}^{2}$ (Nagelkerke) $=0,453$ $\%$ acerto total $=7,9 \%$

A partir do modelo é possível inferir que a chance do governo votar "não" é de quase 4 vezes a chance em comparação à oposição. Os altos coeficientes da estatística de Wald destacam a maior relação entre ideologia e voto e, nesse caso, ser de direita denota uma chance de praticamente $5 \%$ de votar "não" comparado a um parlamentar de direita e centro $1,6 \%$. O percentual de acerto do modelo é de $7,9 \%$.

\footnotetext{
35 CÂMARA DOS DEPUTADOS. PL 1057/2007. Disponível em: $<$ http://www2.camara.leg.br/proposicoesWeb/fichadetramitacao?idProposicao $=351362>$ Acesso em: 21 out. 2015 b.
} 
SCHEEFFER, Fernando. Esquerda, direita e "novos" temas na Câmara dos Deputados. Revista Eletrônica Direito e Política, Programa de Pós-Graduação Stricto Sensu em Ciência Jurídica da UNIVALI, Itajaí, v.12, n.3, $3^{0}$ quadrimestre de 2017. Disponível em: www.univali.br/direitoepolitica - ISSN 1980-7791

\subsection{PLANO NACIONAL DE PARTICIPAÇÃO SOCIAL (PDC 1491/2014)}

Em 23 de maio de 2014 a Presidência da república lança o Decreto 8.243/2014 que institui o que o governo chama de Política Nacional de Participação Social (PNPS) e o Sistema Nacional de Participação Social (SNPS). Ambos os mecanismos têm o intuito de fortalecer e articular os mecanismos e instâncias democráticas, bem como a articulação entre a administração pública federal e a sociedade civil (BRASIL, 2015). Já o decreto legislativo n 1491/2014, buscou suspender o referido decreto, proposta apresentada pelos deputados Mendonça Filho (DEM/PE) e Ronaldo Caiado (DEM/GO). Citando o art. 14 da Carta Magna que cita que a soberania popular será exercida pelo sufrágio universal e pelo voto direto e secreto, a justificativa é de que o plano levaria a uma corrosão do regime representativo, assim como se teria o risco dos rumos das políticas públicas ficarem a mercê da sociedade civil organizada. ${ }^{36}$

Embora fique evidente uma preocupação que o plano não passe de uma estratégia governamental para instrumentalizar a relação com a sociedade civil organizada a fim de conseguir apoio para projetos do seu interesse, prevalecendo o teor políticoideológico espera-se que os parlamentares vinculados a partidos de direita votem "sim", e os partidos localizados à esquerda do espectro ideológico votem "não". Embora o projeto tenha sido aprovado de forma simbólica, a votação nominal a ser analisada trata-se da realizada em 15/07/2014, requerimento $n^{\circ} 10361 / 2014$ que solicita regime de urgência para apreciação do PDC $n^{\circ} 1491 / 2014 .{ }^{37}$

\footnotetext{
36 CÂMARA DOS DEPUTADOS. Projeto de Decreto Legislativo $\mathbf{n}^{\circ}$, de 2014. Disponível em: <http://www.camara.gov.br/proposicoesWeb/prop_mostrarintegra;jsessionid=B2D729A8028F5B9 C9C1BCE852A536290. proposicoesWeb1 codteor $=1258271 \&$ filename $=P D C+1491 / 2014>\quad$ Acesso em: 26 ago. 2015c.

37 A solicitação do regime de urgência é um regime de tramitação que dispensa algumas formalidades regimentais. Normalmente é um recurso utilizado para acelerar a aprovação de um projeto. Desta forma pode ser considerado um artifício equivalente ao voto "sim".
} 
SCHEEFFER, Fernando. Esquerda, direita e "novos" temas na Câmara dos Deputados. Revista Eletrônica Direito e Política, Programa de Pós-Graduação Stricto Sensu em Ciência Jurídica da UNIVALI, Itajaí, v.12, n.3, $3^{\circ}$ quadrimestre de 2017. Disponível em: www.univali.br/direitoepolitica - ISSN 1980-7791

Tabela 5 - Voto "não" decreto legislativo 1491/2014: análise de regressão logística

\begin{tabular}{|c|c|c|c|c|c|c|}
\hline Variável & B & S.E. & Wald & df & Sig. & $\operatorname{Exp}(B)$ \\
\hline Ideologia & & & 65,060 & 2 & ,000 & \\
\hline Ideologia(D) & $-4,002$ & ,576 & 48,248 & 1 & ,000 & ,018 \\
\hline Ideologia(C) & $-5,175$ & 1,049 & 24,343 & 1 & ,000 & ,006 \\
\hline Governo & 2,153 & ,476 & 20,463 & 1 & ,000 & 8,612 \\
\hline Constante & $-1,024$ & ,388 & 6,966 & 1 & ,008 & 359 \\
\hline
\end{tabular}

Quanto ao peso das variáveis, a estatística de Wald revela o maior peso para a variável ideologia. Ser governa representa 8,6 vezes a chance de votar "não" comparado a um parlamentar da oposição. Por sua vez, um parlamentar de direita tem $1,8 \%$ e centro $0,6 \%$ de chance comparado a um parlamentar de esquerda. 0 modelo tem uma porcentagem de acerto total de $9,2 \%$ dos casos.

\subsection{CRIAÇÃO DA COMISSÃO NACIONAL DA VERDADE (PL 7376/2010)}

A chamada Comissão Nacional da Verdade, instituída pelo projeto de lei 7376/2010 e de autoria da Presidência da República, a proposição foi formulada em maio de 2010. Conciso, o texto que cria a comissão tem apenas 13 artigos. Desde que foi proposto foi alterado em vários pontos, principalmente para atender às queixas de militares. ${ }^{38} \mathrm{Na}$ sua versão final o texto prevê que a comissão teria a finalidade de examinar e esclarecer as graves violações de direitos humanos praticadas entre 1946-1988 em busca da verdade histórica e promover o que foi chamado de "reconciliação nacional". Deverá analisar casos de torturas, mortes, desaparecimentos, ocultação de cadáveres, além de identificar e tornar públicas as estruturas, os locais, as instituições e as circunstâncias relacionadas a essas práticas. Sete membros nomeados pela presidente Dilma Rousseff terão acesso a

\footnotetext{
38 O principal temor foi o de ferir a Lei da Anistia que impede a responsabilização penal por crimes políticos cometidos durante a ditadura militar (1964-1985). Outra preocupação era fazer com que a comissão também tratasse de organizações de esquerda que aderiram à luta armada.
} 
SCHEEFFER, Fernando. Esquerda, direita e "novos" temas na Câmara dos Deputados. Revista Eletrônica Direito e Política, Programa de Pós-Graduação Stricto Sensu em Ciência Jurídica da UNIVALI, Itajaí, v.12, n.3, $3^{\circ}$ quadrimestre de 2017. Disponível em: www.univali.br/direitoepolitica - ISSN 1980-7791

todos os arquivos do poder público, além de poder convocar vítimas ou acusados para depoimentos, mesmo sem caráter obrigatório. Ao final de dois anos, prazo de atuação do grupo, a comissão deverá emitir relatório com seus principais achados. ${ }^{39}$

A análise em questão é a da votação do requerimento n 1548/2011 que altera o regime de tramitação da matéria. Aprovado, o PL 7376/2010 passa a tramitar em regime de urgência, recurso utilizado para acelerar a sua aprovação. A votação foi realizada em 21 de setembro de 2011 e indiretamente significa priorizá-lo ou não, rejeitá-lo ou aceitá-lo. Visto que no caso brasileiro a direita tem vínculo com a ditadura militar e a esquerda se diz defensora dos direitos humanos, se esperaria que os grupos agissem em conformidade com esses pressupostos (direita "não" e esquerda "sim").

Tabela 6 - Voto "não" criação da Comissão Nacional da Verdade: análise de regressão logística

\begin{tabular}{ccccccc}
\hline Variável & B & S.E. & Wald & df & Sig. & Exp(B) \\
\hline Ideologia & & & 19,350 & 2 &, 000 & \\
Ideologia(D) & 2,111 &, 518 & 16,593 & 1 &, 000 & 8,254 \\
Ideologia(C) & 1,008 &, 590 & 2,919 & 1 &, 088 & 2,740 \\
Governo &,- 113 &, 352 &, 102 & 1 &, 749 &, 893 \\
Constante & $-3,351$ &, 532 & 39,749 & 1 &, 000 &, 035 \\
$\begin{array}{l}\mathrm{N}=\text { 392; Chi-quadrado }=27,260 ; \text { g.l }=3 ; \text { Sig. }=0,000 ; R^{2} \text { (Nagelkerke) }=0,136 \\
\% \text { acerto total = 0\% }\end{array}$
\end{tabular}

Os valores da estatística de Wald denotam a maior relação entre ideologia e voto, mesmo que de forma discreta. Nesse sentido, ser de direita corresponde a aproximadamente 8 vezes a chance de votar "não" comparado a um parlamentar de esquerda. Não é possível inferir sobre a chance do centro e do governo se

39 GÓIS, F. CCJ aprova Comissão da Verdade com pedido de urgência. 19 out. 2011. Disponível em: <http://congressoemfoco.uol.com.br/noticias/ccj-aprova-comissao-da-verdadecom-pedido-de-urgencia/> Acesso em: 14 mar. 2016. 
SCHEEFFER, Fernando. Esquerda, direita e "novos" temas na Câmara dos Deputados. Revista Eletrônica Direito e Política, Programa de Pós-Graduação Stricto Sensu em Ciência Jurídica da UNIVALI, Itajaí, v.12, n.3, $3^{\circ}$ quadrimestre de 2017. Disponível em: www.univali.br/direitoepolitica - ISSN 1980-7791

comportar visto que os dados não foram significativos. O modelo peca em poder explicativo, se demonstrando frágil.

\subsection{IDENTIDADE DE GÊNERO (PL 7699/2006)}

A noção de identidade sexual, ou de gênero, implica que esta não tem relação direta com o nosso sexo anatômico, ou seja, "[...] é construída também a partir da identificação (ou não) com o sexo anatômico com o qual se nasceu e com a identificação (ou não) com o significado social associado a cada sexo". ${ }^{40}$ Nesse sentido a palavra "sexo" diz respeito ao aspecto anatômico e fisiológico humano, enquanto "gênero" refere-se ao significado atribuído ao sexo, coisas distintas.

O Projeto de Lei n 7699/2006 institui a Lei Brasileira da Inclusão da Pessoa com Deficiência. Conhecido como Estatuto da Pessoa com Deficiência, cria normas para garantir acessibilidade, transporte, moradia e atendimento de saúde específico para pessoas com algum tipo de deficiência. O texto-base foi aprovado em 05/03/2015. Feito isso o plenário passou a apreciar os destaques. O primeiro destaque apreciado, apresentado pelo PRB, pedia a retirada do texto do inciso VI do $\S 4^{\circ}$ do art. 18 da subemenda substitutiva, dispositivo que ressalta respeito à especificidade e à identidade de gênero e orientação sexual da pessoa com deficiência nos atendimentos realizados no Sistema Único de Saúde (SUS). Se esperaria na presente votação que a esquerda defenderia a liberdade de escolhera da orientação sexual (sim); a direita, amparada em uma concepção tradicional de família se posicionaria contra esses direitos (rejeite do texto original, "não").

40 LIMA, R. de L. de. Diversidade, identidade de gênero e religião: algumas reflexões. Em pauta, v. 9, n. 28, p. 165-182, dez. 2011. p. 168. 
SCHEEFFER, Fernando. Esquerda, direita e "novos" temas na Câmara dos Deputados. Revista Eletrônica Direito e Política, Programa de Pós-Graduação Stricto Sensu em Ciência Jurídica da UNIVALI, Itajaí, v.12, n.3, $3^{\circ}$ quadrimestre de 2017. Disponível em: www.univali.br/direitoepolitica - ISSN 1980-7791

Tabela 7 - Voto "não" identidade de gênero: análise de regressão logística

\begin{tabular}{crrrrrr}
\hline Variável & B & S.E. & Wald & df & Sig. & Exp(B) \\
\hline Ideologia & & & 49,223 & 2 &, 000 & \\
Ideologia(D) & 1,849 &, 274 & 45,592 & 1 &, 000 & 6,353 \\
Ideologia(C) &, 604 &, 311 & 3,774 & 1 &, 052 & 1,830 \\
Governo &, 245 &, 238 & 1,064 & 1 &, 302 & 1,278 \\
Sexo(F) &,- 611 &, 423 & 2,088 & 1 &, 148 &, 543 \\
Constante & $-1,150$ &, 261 & 19,343 & 1 &, 000 &, 317 \\
\hline
\end{tabular}

$\mathrm{N}=362 ;$ Chi-quadrado $=61,854 ; \mathrm{g} . \mathrm{I}=4 ;$ Sig. $=0,000 ; \mathrm{R}^{2}$ (Nagelkerke) $=0,210$ $\%$ acerto total $=17,4 \%$

Nessa lei foi inserida uma variável a mais, sexo, para testar se há ou não influência desta na votação em questão. Em relação à variável ideologia, a categoria "centro" se demonstrou pouco significativa, assim como a variável governo e sexo (Sig. = $0,052,0,302$ e 0,148 respectivamente). Por outro lado, ser de direita representa uma chance 6 vezes maior de votar "não" comparado a um parlamentar de esquerda. $17,4 \%$ dos casos podem ser explicados pelo modelo.

\subsection{COTAS PARA MULHERES NO LEGISLATIVO (PEC 182/2007)}

A proposta de emenda à Constituição de n 182/2007, chamada de PEC da fidelidade partidária, contou com a emenda aglutinativa n 57 apresentada pela bancada feminina como proposta a ser incorporada pela reforma política buscando garantir um percentual de vagas no Legislativo para as mulheres. O texto prevê que para as eleições na Câmara dos Deputados, Assembleias Legislativas dos Estados, Câmara Legislativa do Distrito Federal e Câmaras Municipais, para o período de três legislaturas consecutivas, serão reservadas vagas para mulheres nas seguintes proporções: na primeira delas $10 \%$ do total de cadeiras, na segunda legislatura, o percentual subiria para $12 \%$ e, na terceira, para $15 \%$. As vagas deveriam ser preenchidas pelo sistema proporcional. Se a cota não fosse 
SCHEEFFER, Fernando. Esquerda, direita e "novos" temas na Câmara dos Deputados. Revista Eletrônica Direito e Política, Programa de Pós-Graduação Stricto Sensu em Ciência Jurídica da UNIVALI, Itajaí, v.12, n.3, $3^{\circ}$ quadrimestre de 2017. Disponível em: www.univali.br/direitoepolitica - ISSN 1980-7791

preenchida, seria aplicado o princípio majoritário para as vagas remanescentes..$^{41}$ Diante do exposto e se pautando nas colocações sobre ações afirmativas já expostas no corpo do trabalho, espera-se que os partidos de esquerda sejam favoráveis à emenda, já a direita mais reticente.

Tabela 8 - Voto "não" cotas para mulheres no legislativo: análise de regressão logística

\begin{tabular}{ccccccc}
\hline Variável & B & S.E. & Wald & df & Sig. & Exp(B) \\
\hline Ideologia & & & 28,764 & 2 &, 000 & \\
Ideologia(D) & 1,863 &, 348 & 28,715 & 1 &, 000 & 6,443 \\
Ideologia(C) & 1,503 &, 388 & 14,991 & 1 &, 000 & 4,495 \\
Governo &,- 474 &, 253 & 3,507 & 1 &, 061 &, 622 \\
Sexo(M) & 2,704 & 1,027 & 6,925 & 1 &, 009 & 14,936 \\
Constante & $-5,129$ & 1,070 & 22,985 & 1 &, 000 &, 006 \\
$\begin{array}{l}\mathrm{N}=394 ; \text { Chi-quadrado }=57,061 ; \text { g.I }=4 ; \text { Sig. }=0,000 ; \mathrm{R}^{2} \text { (Nagelkerke) }=0,198 \\
\% \text { acerto total = 0\% }\end{array}$ & & & &
\end{tabular}

A relação entre governo e oposição e o voto não se demonstrou significativa, ocorrendo de forma frágil ou então aleatória, enquanto que em se tratando de ideologia ser de centro implicaria em 4,5 vezes a chance de votar "não" e de direita quase 6 vezes e meia comparado a um parlamentar de esquerda. De forma complementar foi inserida a variável sexo. A chance de um homem votar "não" é praticamente 15 vezes a chance comparado a uma mulher. Das 40 mulheres presentes em plenário, apenas uma rejeitou a emenda. Os 100 votos contrários se distribuíram nos 354 parlamentares do sexo masculino restantes. O modelo não se demonstrou muito eficiente.

${ }^{41}$ CÂMARA DOS DEPUTADOS. Proposta de Emenda à Constituição $\mathbf{n}^{\circ} \mathbf{1 8 2}$, de 2007: emenda aglutiva $n^{\circ}$ 57. 
SCHEEFFER, Fernando. Esquerda, direita e "novos" temas na Câmara dos Deputados. Revista Eletrônica Direito e Política, Programa de Pós-Graduação Stricto Sensu em Ciência Jurídica da UNIVALI, Itajaí, v.12, n.3, $3^{\circ}$ quadrimestre de 2017. Disponível em: www.univali.br/direitoepolitica - ISSN 1980-7791

\section{CONSIDERAÇÕES FINAIS}

Os dados da regressão logística buscam dar conta da questão-problema: qual o peso da ideologia na Câmara dos Deputados se atendo à análise de votações nominais envolvendo questões pós-materialistas que se fazem presentes no debate contemporâneo? Havendo concorrência entre duas variáveis substanciais: governo/oposição e ideologia, em temas com cunho ideológico, qual delas se sobressai?

Com nuances diferentes, em todas as votações analisadas a variável ideologia sobrepujou. Chama a atenção a forte relação entre ideologia e voto na votação do Código Florestal Brasileiro, Plano Nacional de Participação Social e rotulagem de transgênicos. A relação consistente entre ideologia e voto na questão ambiental, demonstra ser este um claro divisor de águas entre esquerda e direita.

Os dados empíricos confirmam o maior peso da ideologia, obviamente evocando que as duas variáveis escolhidas se entrecruzam, cada uma delas se demonstrando mais ou menos significativas dependendo do contexto e do que está em jogo na arena política. Citando como exemplo o PL 6738/2013 que trata das cotas para concurso público, longe de ser algo consensual, de forma geral o tom dos discursos não parece condizer com a votação, semelhante ao que ocorreu com o Projeto de Lei 73/1999, que reserva cota para negros, índios e pobres nas universidades federais. Longe de ser algo consensual, com forte lobby externo e depois de firmado um acordo entre os partidos, é aprovado em 20 de novembro de 2008 por votação simbólica no dia da Consciência Negra. ${ }^{42}$

A constatação do papel ainda relevante da ideologia não ratifica o que vem sendo pregado e defendido tanto pelo senso comum quanto pela Ciência Política, pautado na crença de que o fazer parte ou não do governo é o principal determinante do voto e deixaria em segundo plano a coerência ideológica, considerada baixa no

42 CÂMARA DOS DEPUTADOS. Câmara aprova projeto que estabelece cotas nas universidades federais para alunos de escolas públicas. 20 nov. 2008. Disponível em: <http://www2.camara.leg.br/camaranoticias/radio/materias/ULTIMAS-NOTICIAS/360712C\%C3\%82MARA-APROVA-PROJETO-QUE-ESTABELECE-COTAS-NAS-UNIVERSIDADES-FEDERAISPARA-ALUNOS-DE-ESCOLAS-P\%C3\%9ABLICAS-(02'55\%22).html> Acesso em: 14 jun. 2016. 
SCHEEFFER, Fernando. Esquerda, direita e "novos" temas na Câmara dos Deputados. Revista Eletrônica Direito e Política, Programa de Pós-Graduação Stricto Sensu em Ciência Jurídica da UNIVALI, Itajaí, v.12, n.3, $3^{\circ}$ quadrimestre de 2017. Disponível em: www.univali.br/direitoepolitica - ISSN 1980-7791

sistema partidário brasileiro. Diferentemente, o que os resultados aqui encontrados permitem concluir que, mesmo considerando o peso das coalizões partidárias, em temas com caráter ideológico há ainda um debate programático importante e os partidos se posicionam de forma consideravelmente coerente na Câmara dos Deputados.

O debate contemporâneo vai além dos que defendem políticas redistributivistas e os que priorizam o ajuste fiscal, ou ainda, de forma pejorativa, os populistas e os neoliberais. Não é possível afirmar que o sistema partidário brasileiro não se caracteriza por importantes distinções ideológicas, entretanto, tudo indica que vivenciamos uma nova polarização política em que emergem a oposição agora entre, por exemplo, conservadores e progressistas. ${ }^{43}$ Esta dimensão vai além da tradicional escala esquerda-direita pautada em termos de intervenção social na economia. As maiores clivagens entre esquerda e direita talvez se encontrem em temas que excedem a velha discussão relativa a mais ou menos Estado. Empiricamente esse enunciado parece fazer sentido. A partir do conjunto de casos analisados pode-se afirmar que na Câmara dos Deputados os partidos de esquerda e de direita se comportam de forma distinta e consideravelmente previsível e faz sentido ainda falarmos em ideologia dos partidos políticos.

43 TAROUCO, G.; VIEIRA, S.; MADEIRA, R. Mensuração de preferências políticas: análise de manifestos. Revista Política Hoje, 2. ed, v. 24, p. 135-150. 2015. Disponível em: <http://www.revista.ufpe.br/politicahoje/index.php/politica/article/view/395/207> Acesso em: 11 abr. 2016. 
SCHEEFFER, Fernando. Esquerda, direita e "novos" temas na Câmara dos Deputados. Revista Eletrônica Direito e Política, Programa de Pós-Graduação Stricto Sensu em Ciência Jurídica da UNIVALI, Itajaí, v.12, n.3, $3^{0}$ quadrimestre de 2017. Disponível em: www.univali.br/direitoepolitica - ISSN 1980-7791

\section{REFERÊNCIAS DAS FONTES CITADAS}

ALMEIDA, A. C. Ideologia e comportamento eleitoral: evidências de que a ideologia não é importante para explicar o voto. Trabalho apresentado no $25^{\circ}$ Encontro Anual da ANPOCS, Caxambu-MG, 2001.

BOBBIO, N. Direita e Esquerda: razões e significados de uma distinção política. São Paulo: Editora da UNESP, 1995.

BRASIL. Decreto no 8.243, de 23 maio de 2014. Disponível em: <http://www.planalto.gov.br/ccivil_03/_Ato2011-

2014/2014/Decreto/D8243.htm> Acesso em: 26 ago. 2015.

CÂMARA DOS DEPUTADOS. Projeto de lei n 4148 de 2008. Disponível em: <http://www.camara.gov.br/proposicoesWeb/prop_mostrarintegra;jsessionid=4 477655DB192D2965AF0E7CFA2C5C9CD. proposicoesWeb2?codteor $=605180 \&$ file name $=P L+4148 / 2008>$ Acesso em: 03 set. 2015a.

Aprovado projeto que reserva $\mathbf{2 0 \%}$ das vagas em concursos <http://www2.camara.leg.br/camaranoticias/noticias/ADMINISTRACAOPUBLICA/464662-APROVADO-PROJETO-QUE-RESERVA-20-DAS-VAGAS-EMCONCURSOS-FEDERAIS-PARA-NEGROS.html> Acesso em: 17 ago. 2015.

\section{PL}

$1057 / 2007$.

Disponível em: <http://www2.camara.leg.br/proposicoesWeb/fichadetramitacao?idProposicao=3 51362> Acesso em: 21 out. 2015b.

Projeto de Decreto Legislativo ${ }^{\circ}$, de 2014. Disponível em: <http://www.camara.gov.br/proposicoesWeb/prop_mostrarintegra;jsessionid=B 2D729A8028F5B9C9C1BCE852A536290. proposicoesWeb1 ?codteor $=1258271 \&$ file name $=P D C+1491 / 2014>$ Acesso em: 26 ago. 2015c.

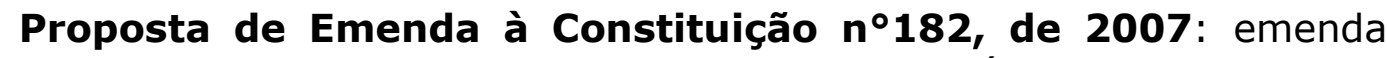
aglutiva $\quad \mathrm{n}^{\circ} 57 . \quad$ Disponível em: <http://www.camara.gov.br/proposicoesWeb/prop_mostrarintegra?codteor $=134$ 9292\&filename $=E M A+57 / 2015+\% 3 D \% 3 E+P E C+182 / 2007>$ Acesso em: 12 set. 2015d.

Câmara aprova projeto que estabelece cotas nas universidades federais para alunos de escolas públicas. 20 nov. 2008. Disponível em: <http://www2.camara.leg.br/camaranoticias/radio/materias/ULTIMASNOTICIAS/360712-C\%C3\%82MARA-APROVA-PROJETO-QUE-ESTABELECECOTAS-NAS-UNIVERSIDADES-FEDERAIS-PARA-ALUNOS-DE-ESCOLASP\%C3\%9ABLICAS-(02'55\%22).html> Acesso em: 14 jun. 2016.

CAMARGO, R. Conheça a emenda vilã do Código Florestal. 28 mai. 2011. Disponível em: <http://congressoemfoco.uol.com.br/codigo-florestal/conheca-aemenda-vila-do-codigo-florestal/> Acesso em: 05 fev. 2015. 
SCHEEFFER, Fernando. Esquerda, direita e "novos" temas na Câmara dos Deputados. Revista Eletrônica Direito e Política, Programa de Pós-Graduação Stricto Sensu em Ciência Jurídica da UNIVALI, Itajaí, v.12, n.3, $3^{\circ}$ quadrimestre de 2017. Disponível em: www.univali.br/direitoepolitica - ISSN 1980-7791

CARREIRÃO, Y. de S. O sistema partidário brasileiro: um debate com a literatura recente. Revista Brasileira de Ciência Política, n. 14. Brasília, mai.-ago. 2014, p. $255,295$.

CUNHA, S. B. da.; GUERRA, A. J. T. (orgs.) A questão ambiental: diferentes abordagens. Rio de Janeiro: Bertrand Brasil, 2003.

DALTON, R. J.; FARRELL, D.; MCALLISTER, I. Political parties and democractic linkage. Oxford: Oxford University Press, 2011.

FARIA, C. F. O que há de radical na teoria democrática contemporânea: análise do debate entre ativistas e deliberativos. Rev. bras. Ci. Soc., São Paulo, v. 25, n. 73, p. 101-111, jun. 2010. Disponível em <http://www.scielo.br/scielo.php?script=sci_arttext\&pid=S0102-

69092010000200006\&lng=pt\&nrm=iso> Acesso em: 14 jun. 2016.

FELLET, J. Câmara aprova Comissão da Verdade: entenda como órgão atuará. 21 set. 2011. Disponível em: <http://www.bbc.com/portuguese/noticias/2011/09/110921_comissao_verdade _qa_jf.shtml> Acesso em: 14 mar. 2016.

FERNANDES, J. P. T. A ideologia do multiculturalismo. Disponível em:<http://recil.grupolusofona.pt/bitstream/handle/10437/4286/a_ideologia_do _multiculturalismo.pdf?sequence =1> Acesso em: 17 mai. 2016.

FREITAS, M. A. A esquerda brasileira em tempos neoliberais. Revista de Ciência Política, Rio de Janeiro, v. 17, 2004.

GÓIS, F. CCJ aprova Comissão da Verdade com pedido de urgência. 19 out. 2011. Disponível em: <http://congressoemfoco.uol.com.br/noticias/ccj-aprovacomissao-da-verdade-com-pedido-de-urgencia/> Acesso em: 14 mar. 2016.

HEYWOOD, A. Ideologias políticas: do liberalismo ao fascismo. São Paulo: Ática, 2010a.

2010b.

Ideologias políticas: do feminismo ao multiculturalismo. São Paulo:

INGLEHART, R. The silent revolution. Princeton: Princeton University Press, 1977.

KINZO, M. D. O quadro partidário e a Constituinte. In: LAMOUNIER, B. De Geisel a Collor: o balanço da transição. São Paulo: Sumaré, 1990.

KOYSIS, D. T. Visões e ilusões políticas: uma análise e crítica cristã das ideologias contemporâneas. São Paulo: Vida Nova, 2014.

KRAUSE, S.; DANTAS, H.; MIGUEL, L. F. (orgs.) Coligações partidárias na nova democracia brasileira: perfis e tendências. Rio de Janeiro: Konrad-Adenauer, 2010. 
SCHEEFFER, Fernando. Esquerda, direita e "novos" temas na Câmara dos Deputados. Revista Eletrônica Direito e Política, Programa de Pós-Graduação Stricto Sensu em Ciência Jurídica da UNIVALI, Itajaí, v.12, n.3, $3^{\circ}$ quadrimestre de 2017. Disponível em: www.univali.br/direitoepolitica - ISSN 1980-7791

LEVIN, Y. The great debate: Edmund Burke, Thomas Paine, and the birth of right and left. New York: Basic Books, 2014.

LIMA, R. de L. de. Diversidade, identidade de gênero e religião: algumas reflexões. Em pauta, v. 9, n. 28, p. 165-182, dez. 2011.

POWER, T. J.; ZUCCO JR., C. Estimating ideology of Brazilian legislative parties, 1990-2005: a research communication. Latin American Research Review, v.44, n.1, 2009, p.218-246.

QUADROS, M. P. dos R. Neoconservadorismo e direita religiosa nos Estados Unidos: formação ideológica, "guerra cultural" e política externa. Espaço Plural, Cascavel, ano XV, n. 31, p. 43-61, 2014. Disponível em: < file:///D:/User/Documents/Textos\%20tese/Artigo\%20conservadorismo\%20e\%2 Odireita\%20religiosa.pdf> Acesso em: 17 mai. 2016.

RIBAS, J. R.; VIEIRA, P. R. da C. Análise multivariada com o uso do SPSS. Rio de Janeiro: Ciência Moderna, 2011.

RIBEIRO, E. A. Valores pós-materialistas e cultura política no Brasil. Maringá: Eduem, 2011.

RODRIGUES, A. Feminismo e nova esquerda: um diálogo em construção. In: ALMEIDA, F. I. de. (org.). O que é ser esquerda hoje? Rio de Janeiro: Contraponto, 2013.

RODRIGUES, L. M. Quem é quem na Constituinte: uma análise sociopolítica dos partidos e deputados. São Paulo: OESP-Maltese, 1987.

ROSAS, J. C.; FERREIRA, A. R (orgs.) Left and right: the great dichotomy revisited. New Castle: Cambridge Scholars Publishing, 2013.

SACCHET, T. Representação política, representação de grupos e política de cotas: perspectivas e contendas feministas. Rev. Estud. Fem., Florianópolis , v. 20, n. 2, p. 399-431, Ago. 2012 . Disponível em: <http://www.scielo.br/scielo.php?script=sci_arttext\&pid=S0104026X2012000200004\&lng=en\&nrm=iso> Acesso em: 13 jun. 2016.

SACHS, I. Espaços, tempos e estratégias de desenvolvimento. São Paulo: Vértice, 1986.

SCAVO, D. G.; BEZERRA, E. M. A crise da democracia liberal e os novos movimentos democráticos. Disponível em: <http://www.sndd2014.eventos.dype.com.br/arquivo/download?ID_ARQUIVO=4 151> Acesso em: 27 mai. 2016.

SPIEGEL, M. R. Estatística. 3. ed. São Paulo: Madron Books, 1993.

TAROUCO, G. Brazilian parties according to their manifestos: political identity and programmatic emphases. Brazilian Political Science Review, São Paulo, v. 5, 
SCHEEFFER, Fernando. Esquerda, direita e "novos" temas na Câmara dos Deputados. Revista Eletrônica Direito e Política, Programa de Pós-Graduação Stricto Sensu em Ciência Jurídica da UNIVALI, Itajaí, v.12, n.3, $3^{\circ}$ quadrimestre de 2017. Disponível em: www.univali.br/direitoepolitica - ISSN 1980-7791

n. 1 p. 54-76, 2011. Disponível em: <http://www.bpsr.org.br/index.php/bpsr/article/view/114/105> Acesso em: 11 nov. 2013.

TAROUCO, G. da S.; MADEIRA, R. M. Partidos, programas e o debate sobre esquerda e direita no Brasil. Rev. Sociol. Polit. Curitiba , v. 21, n. 45, mar. 2013.

TAROUCO, G.; VIEIRA, S.; MADEIRA, R. Mensuração de preferências políticas: análise de manifestos. Revista Política Hoje, 2. ed, v. 24, p. 135-150. 2015. Disponível em: <http://www.revista.ufpe.br/politicahoje/index.php/politica/article/view/395/207 > Acesso em: 11 abr. 2016.

ZUCCO JR., C. Ideology or what? Legislative behavior in multiparty presidential settings. The Journal of Politics, v. 71, p. 1.076-1.092, 2009.

- Esquerda, direita e governo: a ideologia dos partidos políticos brasileiros. In: POWER, T. J.; ZUCCO JR. (orgs). 0 congresso por ele mesmo: autopercepções da classe política brasileira. Belo Horizonte: Editora UFMG, 2011.

Submetido em: julho de 2017

Aprovado em: agosto de 2017 